\title{
Research of the Innovation of Financial Management Mode under Network Environment
}

\author{
Lihua $\mathrm{Hu}^{1, \mathrm{a}}$ \\ ${ }^{1}$ Nanchang Institute of Science \& Technology, Nanchang, Jiangxi, 330108 \\ ${ }^{a}$ email
}

Keywords: Network Environment, Financial Management, Innovation and Development

\begin{abstract}
With the progress and development of modern technology, network technology gradually gained widespread popularity in all walks of life. And an important part of modern enterprise financial management as an integral part of the production process, only on the current model of financial management innovation and improvement, combined with advanced computer network technology, so Chinese enterprises to make effective financial management mode innovation, promoting greater effect to enhance the efficiency of financial management and management quality. In this paper, on the current model of corporate financial management brief analysis of the problems, and on this basis to explore an effective way of innovation and development under the network environment of financial management mode, hoping to bring some help to the development of Chinese enterprises.
\end{abstract}

\section{Introduction}

With the current level of China's economic rise, establishment and development of a modern enterprise system requires more robust and comprehensive system, the implementation of financial financial management is to ensure that corporate financial management objectives are important means of achieving. Therefore, the only modern enterprise combined with their own actual situation, from the actual operating conditions and demand point of view, to build a financial management organization targeted and reasonable, scientific financial management, financial management business has a very important role. In the current network environment, companies only on their financial management model innovation, so that the concept of the times are achieved, and strict with its own development needs, innovation and optimization of financial management, which can be further improved financial management efficiency and quality.

\section{Traditional Financial Management Mode Problems}

With the growing demand for modern people, the modern enterprise system under the traditional business has been unable to meet the public, the cultural industry reform gradually. Now many companies are into the modern reform had come, but these are some of the modern enterprise management, especially financial managers are still stuck in the shackles of the traditional system, and not with the modern enterprise reform and follow reform themselves, which resulted in financial management is still the continuation of the traditional concept of financial management and financial management techniques, which make it incompatible with existing industry and the environment, such as the traditional system the main focus is economic, and the modern enterprise the social benefits can not very concerned about; although the most fundamental basis of modern enterprise survival and development is the economic benefits, but also has a very important social role. So many modern businesses must not only pay attention to social benefits, in their own economic benefit is very focused, which leads to the traditional concept can not meet now and then market competition [1]. Financial management personnel management philosophy of old-fashioned lead to a modern enterprise in financial management now does not match today's market, and it leads the market fails to meet competing demands.

Clear objectives for the development of financial management and choose their mode of modern 
enterprise financial management system is the most fundamental basis, and on the implementation of financial management of modern enterprises to provide direction. Now, however, many modern corporate financial management goal is not a clear financial goal or a target relatively vague, fuzzy financial goals also led many companies lost direction financial management, resulting in a lot of modern enterprise management personnel nature of their work only the role of an accountant, for the day is a statistical money or, worse, a cashier role of knowledge, which enhance the modern enterprise financial management formed a major constraint [2]. In addition, for now, many of the modern enterprise in financial management has not been a relatively sound regulatory system, which also caused the modern enterprise financial irregularities often occur phenomenon. And in the financial management system perfect, if not well, but also make the company's financial management is often in a state of uncontrollable. For example, many companies do not have a good system in financial management, leading to its budget system is not perfect, and even some companies have no budget management, resulting in the phenomenon of spending money, often occur due to the failure of financial crisis. Lack of modern enterprise financial management system severely affected the promotion of corporate financial management.

Financial management to carry out the most important thing is that financial management, financial management level of quality for the financial management of enterprises have a great impact. For now, however the quality of modern corporate financial officers are to be improved. The main reason lies in two aspects: one is some of the modern enterprise financial management for the recruitment of low demand, many of the financial management department staff, whether in their professional or above on the professional quality has a significant shortage; Second it is a modern enterprise depends on ignoring the importance of financial management, there is no follow-up training to be valued at their upper and lower case in the cultural market is growing rapidly, and financial management staff did not get the corresponding financial management training, resulting in financial management in the financial knowledge management can easily become obsolete, and the existing financial management can not be synchronized, restricted the development needs of the enterprise. Both cases have the companies will result in the quality of financial management of modern enterprises are generally not high, the modern enterprise financial management results caused a great impact.

\section{Innovation of Enterprise Financial Management Model under Network Environment}

First, the relevant financial management should be sufficient to analyze and summarize the company's overall value chain, enterprise competitors and their own value chain to conduct a comprehensive study and master, so that the shortcomings of the enterprise in a timely manner to find out, in the enterprise process correctly positioned by the core business forms continue to strengthen the way for enterprise management process improvement and innovation. Second, companies should pay attention to their own meticulous financial management. Let the traditional financial management rugged style of management to be changed, by means of a more detailed plan. Control and accounting, and many other methods, so that the sensitivity of financial management has been improved. Finally, corporate financial risk management for continuous optimization [3]. Construction of the internal control system in the correct and appropriate risk warning system build out, reduce business risk capital financing and funding, so that the financial situation of enterprises has been further improved, the correct financial management concepts established.

First, the central role of computer technology and information network to achieve full awareness and as a basis for the actual situation of enterprises, scientific and reasonable forecast, the budget and the implementation of enterprise rolling re-investment projects, thereby so that the risk of scientific data measured objectives are achieved by using a series of information processing in the actual number of financial management process, thereby allowing the scientific enterprise financial information, effectiveness has been further enhanced. Secondly, indicators and evaluation methods to innovate in order to make the core competitiveness of enterprises has been improved. For example, can be enhanced through the calculation of return on assets to make the knowledge of financial management of statistical accuracy for the long-term development of enterprises to bring 
effective help [4]. Finally, companies should be high on network management and advanced information technology to take advantage of, so that the optimization target corporate financial information resources to be realized. With this all-round management of the whole process, so that transparency can be blurred corporate financial information can be achieved, thereby achieving their overall goals in the process, so that the development needs of enterprise financial management under the network environment has been effectively meet .

Improve the overall quality of modern enterprise financial management should be carried out in two ways, first is the strict requirements of financial management in the recruitment of personnel, financial management, personnel recruitment should have a good overall quality, ability and political integrity requirements of candidates, reject low quality of some obvious candidates, always grip the entrance of financial management personnel to choose the best; the second is to take the flow of corporate financial managers worked regularly on the financial management system of personnel training, trying to learn it At the same time financial management knowledge to do with the times, and strive to cultivate an integrated high-quality corporate financial managers, and those who have not been carried-out management standards to maintain the overall quality of financial management.

\section{Conclusion}

All in all, with the increasing popularity of network technology, the modern enterprise financial management is only through constant innovation, a series of problems for itself the existence of a comprehensive analysis, combined with advanced network technology and computer technology, financial management mode from multiple angles a full range of innovation and development, so that it can in order to achieve long-term development of enterprises, enhance the economic efficiency of enterprises.

\section{References}

[1] Chen Zhi. Network Environment Enterprise Group Financial centralized management selection and construction of $[\mathrm{J}]$. Chinese management information (accounting Edition), 2007, 09: 64-67.

[2] Zhang Weiwei, Li Yan. Group Innovation and Thinking under Network Environment Financial Accounting Management Model [J]. Suppliers, 2015, 46: $172+162$.

[3] Wang Hong. Candice Innovation Network environment for SMEs Financial Management Mode of Thinking [J]. Accounting learning, 2016, 08: 84.

[4] Li Shichao. Innovation Network environment for SMEs Financial Management Mode of Thinking [J]. Modern economic information, 2016, 07: 220-221. 